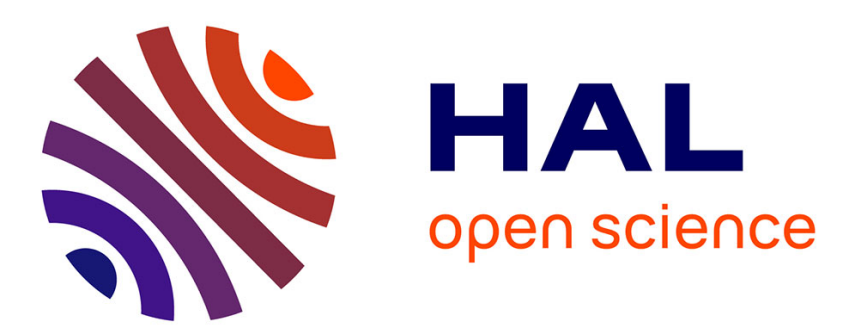

\title{
Coloniality, clonality, and modularity in animals: The elephant in the room
}

Laurel Hiebert, Carl Simpson, Stefano Tiozzo

\section{To cite this version:}

Laurel Hiebert, Carl Simpson, Stefano Tiozzo. Coloniality, clonality, and modularity in animals: The elephant in the room. Journal of Experimental Zoology Part B: Molecular and Developmental Evolution, 2020, 10.1002/jez.b.22944 . hal-02982659

\section{HAL Id: hal-02982659 \\ https://hal.science/hal-02982659}

Submitted on 23 Nov 2021

HAL is a multi-disciplinary open access archive for the deposit and dissemination of scientific research documents, whether they are published or not. The documents may come from teaching and research institutions in France or abroad, or from public or private research centers.
L'archive ouverte pluridisciplinaire HAL, est destinée au dépôt et à la diffusion de documents scientifiques de niveau recherche, publiés ou non, émanant des établissements d'enseignement et de recherche français ou étrangers, des laboratoires publics ou privés. 


\title{
Coloniality, clonality, and modularity in animals: The elephant in the room
}

\author{
Laurel S. Hiebert1,2 | Carl Simpson3 | Stefano Tiozzo2 \\ 1Departamento de Zoologia, Instituto de \\ Biociências, Universidade de São Paulo, \\ São Paulo, Brazil \\ 2Laboratoire de Biologie du Développement de \\ Villefranche - sur - mer (LBDV), Sorbonne \\ Université, CNRS, Paris, France \\ ${ }_{3}$ Department of Geological Sciences and \\ Museum of Natural History, University of \\ Colorado, Boulder, Colorado \\ Correspondence \\ Laurel S. Hiebert, Departamento de Zoologia, \\ Instituto de Biociências, Rua do Matão. \\ Travessa 14. no. 101, Universidade de São \\ Paulo, Cidade Universitaria, São Paulo 05508 - \\ 090, Brazil. \\ Email: laurel.hiebert@gmail.com \\ Funding information \\ Fundação de Amparo à Pesquisa do Estado de \\ São Paulo, Grant/Award Numbers: 2015/ \\ 14052 - 8, 2018/05923 - 3; Centre National de la \\ Recherche Scientifique, Grant/Award Number: \\ PICS 07679; Agence Nationale de la \\ Recherche, Grant/Award Number: ANR - 14 - \\ CE02 - 0019 - 01 \\ The peer review history for this article isavailable \\ at https://publons.com/publon/10. \\ 1002/jez.b.22944
}

Abstract

Nearly half of the animal phyla contain species that propagate asexually via agametic reproduction, often forming colonies of genetically identical modules, that is, ramets, zooids, or polyps. Clonal reproduction, colony formation, and modular organization have important consequences for many aspects of organismal biology. Theories in ecology, evolution, and development are often based on unitary and, mainly, strictly sexually reproducing organisms, and though colonial animals dominate many marine ecosystems and habitats, recognized concepts for the study of clonal species are often lacking. In this review, we present an overview of the study of colonial and clonal animals, from the historic interests in this subject to modern research in a range of topics, including immunology, stem cell biology, aging, biogeography, and ecology. We attempt to portray the fundamental questions lying behind the biology of colonial animals, focusing on how colonial animals challenge several dogmas in biology as well as the remaining puzzles still to be answered, of which there are many.

KEYWORDS

agametic development, allorecognition, immortality, individuality, major evolutionary

transitions, polymorphism, superorganism, units of selection

1 | INTRODUCTION

Most living animals reproduce sexually, a strategy that is regarded as evolutionary advantageous in allowing rapid adaptation to constantly changing environments by providing new gene combinations and removal of deleterious mutations (reviewed by West, Lively, \& Read, 1999).

However, other reproductive modes coexist and at least half of all animal phyla contain species that can propagate asexually via agametic reproduction

(Blackstone \& Jasker, 2003; Buss, 1983a; R. N. Hughes, 1989;

Sköld, Obst, Sköld, \& Ảkesson, 2009). Agametic reproduction differs from parthenogenesis in which unfertilized eggs develop. Instead, agametic cloning occurs when a species propagates asexually, by budding, fission, autofragmentation with subsequent rejuvenation, or production of resting bodies, forming a set of genetically identical modules. The modular units are termed zooids (e.g., in tunicates and bryozoans), ramets, or polyps (e.g., in cnidarians). These units can either remain connected physically and physiologically to one another forming temporary or permanent colonies (Beklemishev, 1969; Blackstone \& 
Jasker, 2003; Boardman, Cheetham, \& Oliver, 1973; R. N. Hughes, 1989; Mackie, Harper, Rosen, \&White, 1986; Rosen, 1979), or stay nearby each other but lose their reciprocal connection forming clones or clonal aggregates (Buss, 1983a). The genetically identical colony or aggregate is often referred to as a genet (R. N. Hughes, 1989).

Though clonal and colonial animals are a major component of global biodiversity (Jackson, 1977), "...so much of the study of ecology and evolution has been based on the behavior of unitary organisms" (Harper, 1985). Thus, animals that adopt clonal reproduction or colony formation challenge ecological and evolutionary theories often developed to implicitly fit populations of sexually reproducing organisms (Harper, 1985; Williams, 1986). The biology of colonial organisms tests the notion of individuality itself and concepts like kin selection, and the inheritance of somatic mutations, extending the hierarchy of units of selection. Asexual ontogenesis hardly fits text - book definitions and categories coined for embryonic development such as the very existence of germ layers or mosaic and regulative development. By replacing (or repairing) modules, colonial organisms can delay senescence and this leads to virtually indefinite growth, defying current evolutionary theories of aging (R. N. Hughes, 1989; Winston, 2010). In this review, we start by presenting an excerpt from the historical perspective of issues raised by animal coloniality. Then, we provide a bird's - eye view of the main aspects of the biology of colonial and clonally - aggregating metazoans and their challenges for ecology, developmental, and evolutionary biology.

\section{2 | SOME HISTORICAL QUANDARIES ON} COLONIALITY

Despite their underrepresented presence in modern biology, fascination for colonial organisms dates back centuries, and the philosophical debate consequently raised is surprisingly rich. Far from providing an exhaustive outline, we focus on selected facets of such debates. Early philosophers and zoologists (dating back to Aristotle's time) noted the similarities of corals, hydroids, bryozoans, and sponges, to the plants, both in terms of their appearance and mode of growth (e.g., Johnston, 1847; reviewed by Gibson, 2012), in fact, until not more than a century ago colonial animals were grouped together as "zoophytes", a term that emphasizes the uncertainty of their affiliation with either animals or plants or even their chimeras. A. Trembley (1710-1784) and J. Ellis (1710-1776), among others, worked on cnidarians ("animal - flowers") and sponges and offered arguably convincing evidence that these species were "compound animals" (Ellis, 1767; Trembley, 1986). This body of zoological studies was later reviewed in popular natural history volumes to help to establish the zoophytes as animals in the minds of naturalists (Buffon, 1804, 1749; Goldsmith, 1774; reviewed by Gibson, 2012). In the Victorian era "compound individuality" became a major philosophical issue (reviewed by Nyhart \& Lidgard, 2011). At the center of this debate was how to define an individual in the context of a colony or in the context of a lifecycle that included alterations in form between generations (T. H. Huxley, 1852; Owen, 1856). On one side of the debate, were the supporters of the idea that "the individual animal is the sum of the phenomena presented by a single life, in other words, all those animal forms which proceed from a single egg taken together" (T. H. Huxley, 1852, p 188). Thus, according to this so - called "poly - organ" theory, a colony would be considered one individual and the parts that arise as buds as mere organs (W. B. Carpenter, 1848; T. H. Huxley, 1852). On the other side were supporters of the "poly - person" theory-the idea that each member of the colony is like a separate individual living in a society (Leuckart, 1851; Vogt, 1847). The debate ran into the late 19th century when cell theory was being developed. Some believed that a multicellular organism could be considered a colony of cells (e.g., Perrier, 1881). This conception led to the organization of individuality into hierarchical levels, from cells to organs to organisms to what Haeckel called a "cormus", (i.e., a colony; Haeckel, 1866) and what Spencer called a "superorganic" aggregate (i.e., a society; Spencer, 1904). It was suggested that as evolution progresses toward higher levels of this hierarchy, the lower levels individuals lose "rights" to the higher levels (Haeckel, 1904). 
Animal coloniality came back into the spotlight in the middle of the 20th century, partly because colonial organisms did not neatly fit into the models of population biology developed around solitary organisms as part of the Modern Synthesis. Beklemishev's $(1950,1969)$ work and set the stage for modern ideas on animal colonies. First, he defined a colony as consisting of individual members that arise asexually from a founder and remain in connection, allowing for the life - long exchange of substances and for the coordination of behavior and growth (Beklemishev, 1950, p 93). Beklemishev also devised a series of evolutionary stages involved in "the weakening of the individuality of zooids" and in the "intensification of the individuality of the colony" eventually reaching "individuals of a higher order" (Beklemishev, 1969).

Harper's (1977) book on plant ecology introduced the concept of modularity in plant forms, which was later extended to colonial animals. Harper used the term module, "a repeated unit of a multicellular structure normally arranged in a branch system," to describe the products of the apical meristem (Harper, 1980). Barrington (1967) and Boardman et al. (1973) helped solidify the modern definition of colonial animals as those whose members are physically connected and who possess common ancestry through asexual reproduction. A 1985 book (Jackson, Buss, Cook, \& Ashmun, 1985), based on a conference on coloniality, emphasized that "the way that a clonal organism occupies space, as connected or disconnected ramets, is fundamental to its prosperity in different situations, both in terms of its functional integration and chance of survival against different forms of adversity." This book also reiterated that "nowhere else do notions of what is an individual, or what are the fundamental units of selection, become more clouded than for clonal organisms." Units of selection was a major topic during this time as group selection was being reinvented in the late 1980s. This brought along the revival of the term "superorganisms", which was used by Wheeler (1911) to describe social insects. The concept was later applied to colonial animals with a superorganism being defined as "a collection of single creatures that together possess the functional organization implicit in the formal definition of organism" (Wilson \& Sober, 1989, p 339). Thus, the ideas related to hierarchy in individuality and evolution reemerged.

\section{3 | DEVELOPMENT WITHOUT AN EMBRYO}

Most colonial and clonal animals reproduce both sexually and asexually and have a disparate array of complex life cycles. Still, during sexual reproduction, the development of the body begins with a fertilized egg, and processes such as cell - fate choice, symmetry

2 | HIEBERT ET AL.

breaking, and axis formation occur in the context of embryogenesis. However, during agemetic clonal propagation, an adult body is built through nonembryonic development (Alié et al., 2018), and the "originator," that is, the cellular source of the emerging new body, is not the fusion of two gametes but somatic cells. Note that this does not include polyembryony, which while constituting clonal reproduction, is a type of embryonic development.

Clonal development necessitates population(s) of somatic stem cells that display different degrees of potency, or by fully differentiated somatic tissues with the ability to dedifferentiate or transdifferentiate, or through the combination of these two mechanisms

(e.g., Cartwright, 2003; Kürn, Rendulic, Tiozzo, \& Lauzon, 2011; Reinhardt, Broun, Blitz, \& Bode, 2004; Sköld et al., 2009).

New modules arise by fission/laceration in a variety of taxa. This includes, but is not limited to, some anthozoans, a number of larval and adult echinoderms, some polychaetes, some nemerteans, xenoturbellids, and some ctenophores (R. N. Hughes, 1989; Sköld et al., 2009). In a number of these species, such as many echinoderms, subsequent regeneration involves the recruitment of undifferentiated cell types (Candia Carnevali, 2006).

New modules may arise by budding to form temporary colonies, such as in phoronids, cycliophorans, some turbellarian flatworms, and trematodes, among others (R. N. Hughes, 1989). In cycliophorans, buds arise from undifferentiated mesenchymal cells in the trunk. In the case of phoronids and many others, the source of the differentiating 
tissue of the bud is unknown (Zimmer, 1991).

Tissue/cell sources underlying budding in true colonies have only been investigated in a few species. In some hydrozoans (e.g., Hydractinia), the interstitial cells ( $\mathrm{i}$ - cells) have the potential to give rise to all tissues of the developing polyp (Frank, Plickert, \& Müller, 2009). Blood - borne circulating stem cells have also been documented to contribute to body tissues in some species of colonial ascidian (e.g., Perophora viridis and Botrylloides leachii; Freeman, 1964; Kassmer, Langenbacher, \& de Tomaso, 2019). In other species of colonial ascidians, such as Polyandrocarpa misakiensis, a new zooid arises mostly from the folding of a parental fully differentiated epithelium that undergoes transdifferentiation (Kawamura \& Fujiwara, 1995). In the hydrozoan Podocoryne, both stem cells and transdifferentiating somatic cells contribute to the formation of the new module (Schmid, Wydler, \& Alder, 1982). Totipotent archeocytes have been documented in demosponges (Alié et al., 2018; Funayama, 2013), although whether sponges can be considered true colonies is unclear (Lanna et al, in review). Whether rhizocephalan barnacles should be defined as colonies is also unclear (Blackstone \& Jasker, 2003), but it has been reported that totipotent stem cells are involved in asexual budding of the interna of the parasitic stage (Shukalyuk, Isaeva, Kizilova, \& Baiborodin, 2005). Interestingly, despite the nature of the originator, somatic mutations can propagate within the colony to the next asexual generation through the budding tissues or even disseminate through the production of propagules (see review by Gill, Chao, Perkins, \& Wolf, 1995). In addition, in several colonial animals, populations of long - lived germline precursors can persist throughout asexual propagation and are also subject to heritable somatic mutations (see Section 6, Brown \& Swalla, 2012; Buss, 1982, 1987; Whittle \& Extavour, 2017). In this sense, nonembryonic development challenges Weismann's paradigm that asserts that heritable variation can only be passed through the germline (Buss, 1987), raising questions about the nature and level of the unit of selection in these organisms. This dilemma has recently been investigated phenotypically in the bryozoan genus Stylopoma, using quantitative genetic techniques (Simpson, Herrera - Cubilla, \& Jackson, 2020). Surprisingly, asexuallyproduced mother and daughter zooids are not morphometrically

similar. In other words, the phenotypic heritability among asexual members is effectively zero. This result is interpreted as an adaptation to prevent colonies from evolving in response to what is likely to be ubiquitous selection among zooid lineages as the colonies grow and compete ecologically. Moreover, colony - level traits, those traits that consist of geometries among and numbers of polymorphic zooids are shown to be heritable among generations of sexually produced colonies. Consequently, Stylopoma preserves Weismann's paradigm but does so at the level of the colony, not the member animal. Nonembryonic development also circumvents the concepts of determinative or regulative development, common to embryology and undertakes completely different ontogenetic pathways, sometimes skipping intermediate stages, that is, larvae and metamorphosis and often, but not always, leading to adult bodies almost indistinguishable from the sexually derived ones (O'Dea, 2006).

The underlying regulatory mechanisms for cell specification and morphogenesis in agametic development appear to have coopted signaling pathways and regulatory modules from their respective embryonic developments (Prünster, Ricci, Brown, \& Tiozzo, 2019a, 2019b; Ricci et al., 2016). For instance, in the ascidian Botryllus schlosseri, young buds reuse "germ layer markers" during a phase of tissue specification, cell type diversification, and spatial rearrangement that may be compared to the drastic cellular and structural changes that occur during embryonic gastrulation. By disrupting the embryonic anteroposterior axis signals, retinoic acid and wnt pathway, axis formation is impaired during cnidarian (Nawrocki \& Cartwright, 2013; Philipp et al., 2009) and ascidian (Di Maio, Setar, Tiozzo, \& de Tomaso, 2015) budding. Genes cassettes that regulate left - right symmetries (Tiozzo \& de Tomaso, 2009; Tiozzo et al., 2005), myogenesis, and neurogenesis (Prünster et al., 2019a, 2019b) have also been shown to be redeployed 
during budding of some ascidians. For regeneration and

fission in some cnidarians, the gene modules from embryogenesis, such as those for cell proliferation, have been shown to be redeployed (Warner, Amiel, Johnston, \& Röttinger, 2019). Even in cnidarian species with true colony - production, such as Hydractinia, some genes originally known from embryogenesis are involved in polyp formation and in the differentiation of polymorphic polyp types (Sanders, Shcheglovitova, \& Cartwright, 2014). Embryonic developmental genes have also been reported in bryozoan budding (Treibergs, 2019) and in siphonophores (Siebert et al., 2011). Interestingly, the species that stand out as having the ability to regenerate the entire bodies from minute numbers of cells (i.e., those HIEBERT ET AL. | 3

capable of "whole - body regeneration", including Hydra, planarians, and some colonial ascidians) are also capable of asexual propagation. In some cases, the results of these two ontogeneses are indistinguishable except for the triggering cause, that is, injury versus asexual lifecycle (Hand and Uhlinger, 1995). Some authors hypothesized that various forms of regeneration could have been originated via the cooption of asexual reproductive processes (Alvarado, 2000). Whole - body regeneration also coopts embryonic regulative mechanisms (Ricci et al., 2016; Tiozzo \& Copley, 2015; Warner et al., 2019) suggesting that both asexual development and regeneration are likely epiphenomena of embryonic development (Tiozzo \& Copley, 2015). Studying nonembryonic development, that is, asexual development and whole - body regeneration, and particularly the cooption of embryonic modules and their rewiring in completely different morphological contexts, are very promising and potentially informative to understand the evolution and the plasticity of the animal developmental program, and perhaps to uncover mechanisms of tissues and organ regeneration (Tiozzo \& Copley, 2015).

4 | SETTING BACK AGING: UNDETERMINED GROWTH AND DELAYED SENESCENCE

Aging, namely the progressive loss of physiological integrity, is different in colonial animals as compared with the aging of unitary animals (Nilsson Sköld \& Obst, 2011; Orive, 1995). Colonial animals constantly add, replace, and repair their modules. Though the lifespan of each ramet is generally constrained, the whole colony ages at a slower rate (Reichard, 2017). Thus, the development, growth, and death of the modules can be considered part of colony homeostasis. Such "extended homeostasis" allows single genotypes to survive for decades or even millennia, like in the case of Caribbean brain coral and some deep - sea corals (Roark, Guilderson, Dunbar, Fallon, \& Mucciarone, 2009) and Antarctic sponges (Dayton, Robilliard, Paine, \& Dayton, 1974).

Colonial animals may undergo cyclical replacement and/or retrogression of functional modules, interfering with the progressive accumulation of somatic problems (mutation, oxidative stress, telomere shortening, accumulation of waste products, etc.) that typically cause aging of unitary organisms (Kirkwood \& Austad, 2000; López - Otín, Blasco, Partridge, Serrano, \& Kroemer, 2013). For example, some colonial ascidians undergo "takeover," whereby old zooids undergo cell death and are replaced by newly - formed buds (Lauzon, Rinkevich, Patton, \& Weissman, 2000). Bryozoans also undergo cyclical regression of the polypides (brown body formation) andrenewal (reviewed by Gordon, 1977). Brown body formation, that is, degenerating zooids, has also been observed in colonial hemichordates (Stebbing, 1970). Thecate hydrozoans also have cycles of degeneration and regeneration and entoprocts periodically renew their calyx (Crowell, 1953;

Harmer, 1886). Cycles of replacement and renewal are also found in nonaggregating clonal species such as some cnidarians and flatworms (Bosch, 2009; Saló, 2006).

Further contribution to the longevity of a colony comes from the ability of many species to go dormant, that is, modules or whole colonies enter a state of physiological and morphological inactivity usually by structurally simplifying their body and enriching them with population(s) of undifferentiated cells (Cáceres, 1997; Coma, Ribes, Gili, \& Zabala, 
2000). Other processes of structural simplification that contribute to extend the lifespan and to delay senescence of the genet occurs during cyclic retrogression to "younger" developmental stages. It is the case of hydrozoan known as "immortal jellyfish" (Turritopsis; Piraino, Boero, Aeschbach, \& Schmid, 1996), in which the mature reproducing medusa can degenerate, undergo cellular reorganization, and form a new larval polyp. Some scyphozoans show similar simplification processes (He, Zheng, Zhang, \& Lin, 2015), which have been described as "tissue saving" (Silveira, Jarms, \& Morandini, 2002) or "reverse development" (Piraino, de Vito, Schmich, Bouillon, \& Boero, 2004).

One of the basic assumptions of the classic evolutionary theories of aging is the early separation between somatic cells and germline (Kirkwood, 1977; Medawar, 1952; Weismann, 1893). The trade - off between germline protection versus somatic cell repair is the main hypothesis for functional and reproductive aging (Maklakov \& Immler, 2016). As introduced in the previous chapter, in clonal animals this distinction is not always straightforward (Blackstone \& Jasker, 2003; Siebert et al., 2015; Simpson, 2011): modules may keep recruiting germline precursors in their body and somatic cells can retain toti/multipotency (see Section 3, Buss, 1983b; Extavour \& Akam, 2003). One consequence is an altered balance between soma and germline (Buss, 1983b). It is important to point out that the germ soma distinction emerges at the colony level in species that are polymorphic (Simpson, 2012). Across polymorphic species, sexual zooids tend to become increasingly rare as the number of other polymorph types increases. In light of the germline hypothesis of aging, it would be interesting to know whether or not highly polymorphic species age differently than less polymorphic species. If not, this result at the whole - colony level may in turn shed light on the evolutionary role of the germline at the cellular level.

Telomerase attrition, stem cell exhaustion, and other hallmarks of aging (López - Otín et al., 2013) are mainly studied in unitary organisms. However, the molecular and cellular mechanisms that lie behind the longevity and the extended senescence of colonial and modular organisms are being uncovered in a few clonal species (Nilsson Sköld \& Obst, 2011; Orive, 1995). Stem cell exhaustion is bypassed by a modification to cell cycle (G2 pausing, promoting DNA repair) and spatially - restricting the location of stem cells in Hydra (Buzgariu, Crescenzi, \& Galliot, 2014). Hydra also relies on insulin and autophagy pathways to regulate nutrient - sensing to maintain the lifespan. Hydra has mechanisms to bypass mitochondrial dysfunction as well via constant activation of DNA repair pathways (reviewed by Schenkelaars et al., 2017). In two colonial ascidians telomerase activity, which is usually low in adult tissues, increases both in developing buds and in putative stem cells (Laird \& Weissman, 2004; Nilsson Sköld \& Obst, 2011). High telomerase activity has also been found in two marine demosponges, Hydra, and asexual, but not sexual planarians (Koziol, Borojevic, Steffen, \& Müller, 1998; Tan et al., 2012). Epigenetic alterations are limited in the stem cells of Hydra and high 4 | HIEBERT ET AL.

cell turnover limits the accumulation of misfolded proteins (loss of protein homeostasis). However, telomerase activity and telomere length were found to be lower in one ascidian species propagated for years in the laboratory compared to their offspring, suggesting that molecular senescence does occur during agametic growth (Sköld, Asplund, Wood, \& Bishop, 2011). But this is a species that sexually produces dormant eggs that allow for the survival of the winter, suggesting that selection pressure for maintaining telomerase activity beyond a year might not be present in the natural population. Indeed, models show a trade - off between sexual versus clonal reproduction that may or may not result in selection for clonal senescence (Gardner \& Mangel, 1997). A better understanding of the genetic, epigenetic, and cellular processes involved in the diversity of colonial/clonal life cycles may provide breakthroughs in the science of aging, rejuvenation, and developmental biology in general (Nilsson Sköld \& Obst, 2011). 
distinct body types termed polymorphs. Polymorphs in colonial animals presumably evolve through similar evolutionary processes as the castes in eusocial insects and the cell types in multicellular organisms (Harvell, 1994; Simpson, 2012).

The benefits of polymorphism are likely to be profound because, through their diversity of functions, they allow an organism to operate efficiently (Beklemishev, 1969; J. Huxley, 1912; Weismann, 1893). The ecology of species that lack polymorphism must either adjust their physiology to accommodate changing environments or remain simple. Nevertheless, most group - living animals (including social insects and vertebrates along with colonial marine invertebrates) lack polymorphism — of the 226 independent origins of group - living, 172 lack polymorphism of any kind (Simpson, 2012).

Polymorphism has evolved in at least 10 phyla of animals (Beklemishev, 1969; Costa, 2006; Harvell, 1994; Wilson, 1975). Extreme polymorphism, with three or more polymorph types occurring within the same colony, is common in cnidarians, particularly in siphonophores (Dunn, 2009; Mackie et al., 1986; Munro et al., 2018; Pugh, 2003) and other hydrozoans

(Cartwright \& Nawrocki, 2010), bryozoans, especially the cheilostomes (D. J. Hughes \& Jackson, 1990; Lidgard, Carter, Dick,

Gordon, \& Ostrovsky, 2012; Schack, Gordon, \& Ryan, 2019; Silén, 1977; Simpson, Jackson, \& Herrera - Cubilla, 2017), and in doliolid tunicates (Deibel \& Lowen, 2012; Harvell, 1994). Schack et al. (2019) provides a wonderful recent review of the variety of polymorph types in marine invertebrates.

The independent origins of polymorphism in different phyla surprisingly share many general features (Beklemishev, 1969; Harvell, 1994; Lidgard et al., 2012; McShea, 2001; Simpson, 2012; Wilson, 1975). These similarities arise as convergent solutions to shared evolutionary problems. And in some cases, the rate at which novelties originate may reflect group - specific constraints (Jablonski, Lidgard, \& Taylor, 1997).

Polymorph types in fossil and living colonial invertebrates tend to exhibit discrete differences (Carter, Gordon, \& Gardner, 2010a; Lidgard et al., 2012). In bryozoans, the conceptual model for the origin of polymorphism is a gradualistic divergence (Banta, 1973; Cheetham, 1973; Silén, 1977). The cheilostome genus Steganoporella possess morphologically similar A - and B - zooids and serves as an exemplar of this possible mode of evolution (Banta, 1973; McKinney \& Jackson, 1989; Silén, 1977), but surprisingly there are few other examples (another possibility is the apical polyp in acroporan corals which is a little taller than other polyps).

The paucity of slight and gradualistic differentiation may, in fact, be informative. Inheriting multiple polymorph types across a colonial lifecycle is likely to be difficult and the first step is incorporating a unicellular stage in the lifecycle (Grosberg \& Strathmann, 1998; Simpson, 2011, 2012). Furthermore, the evolution of inheritance may underpin the empirical observation that when polymorphism first evolves in a species the first division of labor is always reproductive. One of the polymorph types maintains sexual competency and functions as the reproductive specialist, whereas the remainder of polymorph types lack sexual ability (Simpson, 2012). Intriguingly, all phyla exhibit the pattern that the rarity of the sexual specialists decline in frequency as additional polymorph types evolve (Simpson, 2012). Although, why and how polymorphism evolves remains a mystery, it involves the evolution of colonial life cycles and the packaging of inheritance of the suite of polymorphism through a restricted number of reproductive specialists. Despite the similar evolutionary function among sexual polymorphs, at least in bryozoans, there is a remarkable diversity of forms that the sexual specialists take on including specialized structures that evolved from complexes of polymorphs that allow patterns of convergence to be identified (Ostrovsky, 2013; Ostrovsky \& Taylor, 2005).

Given that colonial marine invertebrates are clonal, their polymorphism represents a crystallization of one of the most vexing problems in evolution and developmental biology-how do extreme phenotypic differences evolve with a minimum of genotypic change (Gould, 1977). The expression of many phenotypes with one (clonal) 
genotype must involve some sort of phenotypic plasticity. Evo - devo work on siphonophore polymorphism has highlighted the role of celllevel developmental processes in colony - level phenotypes (Dunn, 2005; Dunn \& Wagner, 2006). Of particular importance are localized growth zones and the maintenance of populations of undifferentiated $i$ - cells within them (Siebert et al., 2015), which likely permits differences in polymorphic body types to evolve just as modular characters within an organism do.

Many polymorph types are also facultative (Harvell, 1991) and colonies may be coordinated by decentralized mechanisms at unity of modules level, particularly in bryozoans. In some bryozoan genera such as genera within the Candidae (Vieira, Spencer Jones, Winston, Migotto, \& Marques, 2014), both facultative and obligatory polymorphs may be present in the same colony. Lang (1921) points out the implausibility of inducible polymorphism being an evolutionary HIEBERT ET AL. | 5

path towards stable polymorphism because the simplest colonies phenotypically will need to be the most complex in terms of genetic regulation. What facultative and inducible polymorphism show, is that polymorphs are expensive to maintain given their inability to feed.

For any phenotypic trait to evolve, it requires preexisting variation for the section to act. This is true for polymorphism as well. The initial origin of reproductive specialization may provide a clue as to where the phenotypic variation that polymorphism evolves from initially arose. All organisms possess a juvenile phase in which they lack reproductive capacity and additionally phenotypic variation over ontogeny can be extreme, especially with allometric growth. The stunting of juvenile development provides a possible mechanism for increasing phenotypic variation and introducing a reproductive division of labor. In this way, it is possible to conceive of doliolids or siphonophores as consisting of many parts of a complex lifecycle cooccurring together.

Ontogenetic truncation is similar but not strictly identical to heterochrony. Moreover, allometry, norms of reaction, and other expressions of the ability for a genotype to produce multiple phenotypes are likely to be involved in the evolution of polymorphism.

Additional processes, such as the complexity drain, where organisms within hierarchical wholes (cells in a multicellular organism or animals within a colony) are less complex than their free - living counterparts (McShea, 2002; McShea \& Changizi, 2003), are likely to be involved. One example of this in colonial invertebrates involves the modified function and simplification observed among different types of polymorphic avicularia in cheilostome bryozoans. Here, the polypide

(food - gathering apparatus associated with a gut) in avicularia are reduced and feeding and other abilities are lost compared with the ancestral autozooid form (Carter, Gordon, \& Gardner, 2010b). In polymorphic species, the polymorphic animals within a colony lack much of the functionality of their solitary ancestors. This extreme phenotypic modification is possible only by virtue of the connectivity of animals within a colony, where other members of the colony can sustain the life of their reduced and modified colony mates.

\section{6 | ECOLOGICAL SIGNIFICANCE OF \\ COLONIALITY}

The modular organization, physical connectivity, and clonal nature have important ecological consequences for the evolutionary potential of colonial animals (Burgess et al., 2017; R. N. Hughes, 2005). Often, colonial animals are constructed out of autonomous modules that can survive independently as well as connected. Because of this functionally autonomous modularity, colonial animals escape a number of constraints on growth and shape relative to their solitary counterparts. The release of these constraints allows for extensive morphological plasticity and flexibility (Kim \& Lasker, 1998; Marfenin, 1997). For example, colonies can grow in various directions and even compete/ overtake other sessile species that do not have such expansive capacity (Jackson, 1977). The capacity for directional growth allows for exploitation of patchy resources and for the selection of spatial refuges, away from predators, competitors, and physical disturbances 
(Buss, 1979). Colony - level morphological plasticity also allows colonial forms to survive after partial predation, death, or damage (Berning, 2008; Hiebert, Vieira, Dias, Tiozzo, \& Brown, 2019). However, regeneration comes with a potential cost-sponges and corals show reduced somatic growth, reduced sexual reproduction, and impaired ecological interactions after regeneration (Henry \& Hart, 2005).

Reduced constraints on growth of colonies allow for an increase in biomass, and may even permit indeterminate growth. As modular animals can take up food across their whole surface and have the potential for sharing resources between members, their overall mass does not necessarily scale with their metabolic rate, unlike most solitary animals (Burgess et al., 2017). With extensive plasticity in their morphology, colonial animals can make colony - level adjustments in response to the environment (Jackson \& Coates, 1986). For example, a colony can adjust reproductive allocation (favoring asexual or sexual) with changing conditions or seasons (Nekliudova et al., 2019). Modular organisms may also adjust budding and branching patterns based on the local environment (Harper, 1977). Colonies with polymorphic zooid types may change the proportion of each morph to meet the needs of the living conditions, increasing defensive morphs if predators are abundant, for example (Harvell, 1990).

Many colonial species can undergo dormancy during unfavorable conditions. For example, freshwater bryozoans possess asexually derived structures called statoblasts that are able to withstand desiccation and other extremes that are common in freshwater systems. In some species, individual modular units in a colony undergo cycles of degeneration and regeneration (see Section 4), a process termed modular senescence (Palumbi \& Jackson, 1983). In other cases, whole colonies seasonally degenerate and develop into resistance forms that survive to regenerate when conditions improve (Jackson \& Coates, 1986).

Although colonial animals are widely distributed and present in a range of habitat types, they are found much more frequently, and with higher diversity, in some regions than others. For example, colonial forms may be rare in the intertidal and soft - sediment marine habitats (Jackson, 1977), although this is not true for all colonial species, such as bryozoans (Ryland, 1976). Colonial species are a dominant and highly diverse component of hard - substratum marine communities. Colonial tunicates appear to be more diverse in tropical and subtropical waters than in temperate and polar regions. It is possible that these latitudinal trends in diversity and abundance may be driven by the ability of colonial forms to withstand predation, their high competitive abilities, and their low susceptibility to fouling and overgrowth-all are traits favored in the highly diverse low latitudes, where substrata is limited and predation is high (Hiebert et al., 2019; Jackson, 1977; Kott, 1981). Scleractinian corals are also highly diverse in the tropics (Veron, Stafford - Smith, DeVantier, \& Turak, 2015). However, polar bryozoans are very diverse and abundant (Hayward, 1995; Kluge, 1975). The diversity of many other colonial taxa remains understudied.

6 | HIEBERT ET AL.

Parental care of offspring occurs more often in colonial species than in solitary (Ramirez, 2002). For example, most colonial tunicates brood embryos while most solitary tunicates are free - spawners. Brooding is also common in hydrozoans and octocorals (Bouillon, Gravili, Pagès, Gili, \& Boero, 2006; Coelho \& Lasker, 2014) and the vast majority of bryozoans incubate their young (Ostrovsky, 2013). Larvae of brooding colonial animals are often developmentally advanced at the time of release and often settle nearby (Jackson \& Coates, 1986). Other modes of dispersal such as colony fragmentation also permit short - distance dispersal (O'Dea, 2006; O'Dea, Jackson, Taylor, \& Rodriguez, 2008; O'Dea, Ostrovsky, \& Rodriguez, 2010). Such modes of dispersal might be advantageous for colonial forms that are already adapted to take advantage of patchy resources, as larvae or colony fragments with long dispersal abilities that wander too far would be selected against. In likes of Baker's law (Baker, 1955; Stebbins, 1957), uniparental asexual reproduction, is expected to provide selective advantageous in colonizing situations for example, along an invasion front, or when colonizing disturbed habitats 
(Pannell et al., 2015). Yet, this strategy is expected to have the long - term effect of increasing extinction rates (Goldberg et al., 2010; Jackson \& Coates, 1986). O'Dea and Jackson (2009) found that environmental changes that occurred during the closure of the isthmus of Panama lead to a shift in the dominant reproductive strategy (sexual founding or asexual fragmentation) within the cupuladriid bryozoans.

Another consequence of limited dispersal is that siblings, their parents, and even clonal - twins are often living side - by - side (Jackson \& Coates, 1986). Thus, recognition of self versus non - self (and close relative) is likely useful in natural conditions (see next session).

\section{7 | WHEN COLONY MEET COLONY:}

\section{PUZZLING ASPECTS OF}

\section{ALLORECOGNITION}

Most colonial invertebrates such as many cnidarians, bryozoans, and ascidians are sessile and encrust benthic environments. While growing and competing for space they often encounter conspecifics with either no, or some degree of kinship. Once they come into contact, two (or more) colonies can maintain their physically separate identities either by activating an "aggressive" response or by coexisting peacefully and neighboring each other. Occasionally, colonies can undergo somatic fusion, sharing resources and forming genetic chimeras. Though aggressive rejection can put the colony at risk, the cost is balanced by the potential benefit of competition for space. In some cases, colony formation occurs by the fusion of nonclonal (sexually derived) individuals such as in the case of some hydrozoans (Chang, Orive, \& Cartwright, 2018; Nawrocki \& Cartwright, 2012). Somatic fusion also has consequences on the fitness of each of the encountering partners. As mentioned in the previous chapter, from an ecological perspective an immediate benefit of fusion is an increase of size: larger colonies have better foraging capacity, produce more gametes, and are more likely to survive predation, physical damage, or diseases (Grosberg, 1988). A larger colony can also more efficiently colonize spatially separated substrates (Buss, 1982). It has also been suggested that fusion of non - genetically identical colonies can produce "chimeric vigor" via increasing genetic diversity, which could be advantageous for adaptation to rapidly changing environments (M. A. Carpenter et al., 2011; Grosberg, Hedgecock, \& Nelson, 2012). On the contrary, if the sharing is not equitable for both genets the fusion could represent a compelling cost for the loser. For instance, we have outlined in Sections 3 and 4 that some colonial species retain both somatic toti/multipotent stem cells, which are responsible for their asexual developments, and long - lived germline precursors (Brown et al., 2009). During fusion, these cell populations can circulate between two colonies and compete for establishing the germline and the soma throughout the life of the colony (Cadavid, 2005; Stoner, Rinkevich, \& Weissman, 1999). In other words, through parasitic stem cells, one colony can force another one to produce its own gametes or change its soma. Indeed, this represents another cost of fusion.

The occurrence of fusion or rejection depends on the degree of compatibility between colonies, which is mediated by allorecognition systems that ultimately gives the colony the ability to distinguish between self and non - self (Grosberg, 1988). The molecular mechanisms of allorecognition have been mostly studied in colonial ascidians (de Tomaso, 2006; Voskoboynik \& Weissman, 2015), Hydractinia (Grosberg, Levitan, \& Cameron, 1996), and the sponge Amphimedon queenslandica (Grice et al., 2017) but have also been reported in other cnidarians and bryozoans (Hughes, Manríquez, Morley, Craig, \& Bishop, 2004). Allorecognition is generally controlled by one locus, which allows somatic fusion only if the alleles are shared (de Tomaso et al., 2005; Grosberg et al., 1996; McKitrick \& de Tomaso, 2010). The strategy works because allorecognition loci are extremely polymorphic, making it unlikely that completely unrelated genets fuse together.

The genes at these loci are known to code for cell - surface proteins or extracellular proteins, but the nature of the binding partners of those proteins, and thus, how one colony actually recognizes another, is not fully resolved. The evolution and maintenance of highly polymorphic allorecognition systems in colonial animals is also not fully clear but is 
probably the outcome of a complex network of selective pressures highlighted by the many costs and benefits linked to somatic fusion as well as to the presence of somatic and germline parasitism (Brusini, Robin, \& Franc, 2013; de Tomaso, 2006).

The homology of the allodeterminant genes and downstream signaling pathway is also unclear. More information about these pathways in the current models and the allorecognition systems in additional taxa may provide evidence for the evolutionary origins of the polymorphic loci involved in invertebrate allorecognition and possible links with the vertebrate immune system (Nicotra, 2019; Rosengarten \& Nicotra, 2011; Rosental et al., 2018).

\section{8 | EVO - DEVO AND THE RETURN OF THE INDIVIDUALITY PROBLEM?}

Recent work on the developmental mechanisms underlying clonal propagation shows that tissues and cells that drive budding HIEBERT ET AL. | 7

(“__ originators") are widely divergent between clades (see Section 3). This supports the view that agametic development evolved convergently many times across the animal phylogeny. On the basis of the distribution of agametic developmental modes, coloniality and clonal aggregation are likely to have evolved independently within many separate phyla: once at the base of bryozoans (Schwaha, Ostrovsky, \& Wanninger, 2020), at least four times in cnidarians (and was lost and gained many times; Barbeitos, Romano, \& Lasker, 2010; Kayal et al., 2018), six or seven times in tunicates (Alié, Hiebert, Scelzo, \& Tiozzo, 2020), once within kamptozoans, and once or twice within hemichordates. Two families of rotifers are also known to form clonal aggregates (Wallace, 1987). This suggests that agametic cloning is a highly evolvable trait with a possible selective advantage. Some true colonies have relatives who form temporary colonies or aggregates. It is intriguing to consider whether some block to the separation mechanism or the emergence of a skeleton/tunic may have contributed to the origins of true colonies from temporary ones. However, many colonial taxa have no clonal relatives, hinting that coloniality may not always be preceded by a form of clonality. Either way, both coloniality and clonality within the animals are often found in taxa with high regenerative capacity, suggesting that mechanisms for regeneration may have been recruited/modified in the origins of agametic development (Nilsson Sköld \& Obst, 2011).

It appears that asexual species have mostly appeared recently in the fossil record, suggesting that they may be more susceptible to extinction (Maynard - Smith, 1978). The true number of gains and losses of coloniality and clonality, the underlying developmental and evolutionary mechanisms responsible, as well as speciation and extinction rates linked to these life histories, are poorly understood.

Future work will help elucidate how colonial forms evolved from solitary ancestors repeatedly in evolutionary history.

The evolution of polymorphism is a further mystery with developmental underpinnings. The phenotypes of many polymorph types seem to be allometric modifications of the body type from which they are derived (Banta, 1973; Harvell, 1994). Moreover, the spatial distribution of polymorphism is more often nonrandom than random, especially in siphonophores (Siebert et al., 2015) and erect bryozoans (Hageman, 2001). In branching colonies, including bryozoans and siphonophores, the patterns of polymorphism seem to be structured into repeated modular units, each containing several polymorph types, in a way that is reminiscent of meristematic growth in plants.

Even early researchers saw similarities between plants and colonial animals. Erasmus Darwin wrote: "If a bud be torn from the branch of a tree and cut out and planted... or inserted in the bark of another tree, it will grow, and become a plant in every respect like its parent. This evinces that every bud of a tree is an individual vegetable being, like the polypus... or the branching cells of the coral - insect..." (Darwin, 1800). Each plant bud has the same potential as a bud in a colonial animal, yet we do not think of tree "colonies" arising evolutionarily from incomplete asexual reproduction. Instead, the origin of plant modularity is explained by the emergence of 
metamerism, with metameric growth underlined by stem cells and growth zones (see Barlow, 1989). This is a remarkable degree of convergence between plants and branching colonial animals, which have similar growth modes (van Valen, 1978). The question is how colonial animals evolved the ability to grow in repeated units of hierarchically organized modules (Munro et al., 2018).

With polymorphism, and its packaging into cormidia or sets of polymorphs, modularity occurs at more than one level within a colony - the cell level, within a zooid, the zooid level, and at a hierarchically more inclusive level of sets of zooids (Lidgard et al., 2012).

The dominant hierarchical level at which the modularity occurs has implications and consequences for evolutionary and developmental mechanisms. At one extreme is modularity at the tissue/organ/bodypart level (just the organs, tissues, or set of cell types for example), which can occur in even the simplest colonial organisms. At the other extreme are siphonophores and some bryozoans, where sets of polymorphic zooids always occur and whole - colony differentiation arises to variation among these multizooidal sets across the colony. Therefore, it will be useful to know the level at which the modular units are repeated and whether or not they have distinct consequences for the evolvability of development and morphological complexity or if they impose constraints in development or evolution. This is a more concrete way to frame the units of selection problem. Instead of trying to identify the unit at which selection occurs the strongest, we instead suggest trying to understand the levels at which the evolutionary potential is the strongest. There are hints that more complex colonies tend to have increasingly rare reproductive members (Simpson, 2012) and that the patterns of evolutionary potential within different hierarchical levels within and among colonies do vary (Simpson, Herrera - Cubilla, \& Jackson, 2020). Both observations imply that the macroevolution of coloniality is largely controlled by developmental processes. What these developmental processes are is still totally unknown.

\section{9 | CONCLUSIONS}

Colonial and clonal animals have received less attention than unitary, strictly sexually reproducing species in many fields of biological sciences. Nevertheless, it has long been apparent that the evolution of coloniality is at the locus of the major problems within evolutionary biology, ecology, and developmental biology. Clonality and coloniality have been gained and lost several times across different taxonomic ranks of metazoans. Their scattered distribution clearly shows how these traits have been independently acquired (Figure 1). Such events of convergence support the view that agemetic development may have some adaptive value. Despite their widespread occurrence, impact on many ecosystems and habitats, and the influence on population dynamics, very little is known about how asexual propagation and coloniality have evolved and how their mechanisms are regulated at a genetic and molecular level.

The origin of cells, multicellularity, and eusociality (the evolution of "superorganisms") have all been prominent topics of evolutionary biology. These so - called "major evolutionary transitions" or "evolutionary 8 | HIEBERT ET AL. transitions in individuality" are transformations of previously independent entities into new higher - level wholes (Buss, 1987; Szathmáry \& Smith, 1995). This conceptual framework has been used to understand how hierarchical complexity arose during the evolution of life on Earth and has been key to understanding the origins of cooperation and conflict, self - organization, the origins of modules at various levels, evolvability, multilevel selection, and many more fundamental concepts in biology. Transitions to coloniality and clonal aggregation can be treated in a similar way and may serve as useful models to understand how major evolutionary transitions occur. Thus, colonial animals may help address fundamental questions in the origins of life's hierarchy: how an individual at a higher - level emerges from a collection of lower levels individuals, and how those individual units become integrated and, possibly, specialized.

During the transition to coloniality, a number of emergent properties arose due to the higher level of organization. The fact that there is redundancy across the colony (i.e., multiple similar modules) allows 
for the release of certain constraints on growth and form that give colonies extreme plasticity in shape, size, age, and ecological niche. There is also a release of evolutionary constraints on single modules that allow for specialization to occur at the module level. A release of particular developmental constraints allows for the building of an adult body without the need of sexual reproduction and thus, the colony exhibits exceptional regenerative capacity. Finally, the growth of encrusting colonies allows for the need of a self/non - self recognition system. All of these traits together form a set of evolutionary novelties of colonial animals and may in part underlie the transitions from unitary to colonial. However, which are the driving forces in this major transition and which are mere consequences is still uncertain.

ACKNOWLEDGMENTS

We want to thank Federico Brown, Rick Grosberg, Leandro Manzoni, Alvaro Migotto, Andre Morandini, and the students of the course on "Evolution of coloniality and modularity" (CEBIMar, Nov. 25-Dec. 8, 2018) for the excellent discussions and shared opinions on the questions raised in this review. We also thank the two reviewers for feedback on the manuscript. This study was supported by FAPESP fellowships (2015/14052 - 8 and 2018/05923 - 3) to L. H. and ANR (ANR - 14 - CE02 - 0019 - 01) and CNRS (PICS 07679) to S. T. ORCID

Laurel S. Hiebert http://orcid.org/0000-0001-7756-1066

Carl Simpson http://orcid.org/0000-0003-0719-4437

Stefano Tiozzo http://orcid.org/0000-0003-2822-2783

FIGURE 1 Phylogenetic distribution of colonial and clonal traits within the metazoans. Traits associated with coloniality and clonality are mapped on

a summary tree of metazoan phyla. Agametic cloning (i.e., the ability to produce a new ramet/module by a nonembryonic asexual process) is indicated by

a circle. The color of the circle indicates the source of tissue/cells from which the new modular body originates, at least partially (black一totipotent stem

cells, or pluripotent cells or tissues, white-potency of the cells/tissues is unknown). The black square indicates the presence of permanent colonies. The

triangle indicates groups that display species with polymorphism across modules within a colony (black—extreme polymorphism with three or more

types, white—one to two types). Assignment of traits modified from Sköld and Obst (2011), Blackstone and Jasker (2003), and Harvell (1994). Question

marks indicate cases where clonality and clonality are not certain-in sponges and in rhizocephalan barnacles. Insect polymorphism is omitted because insects do not form true colonies according to the definition used here [Color figure can be viewed at wileyonlinelibrary.com]

HIEBERT ET AL. $\mid 9$

REFERENCES

Alié, A., Hiebert, L. S., Simion, P., Scelzo, M., Prünster, M. M., Lotito, S., ...

Tiozzo, S. (2018). Convergent acquisition of nonembryonic development

in Styelid Ascidians. Molecular Biology and Evolution, 35, 1728-1743.

Alvarado, A. S. (2000). Regeneration in the metazoans: Why does it

happen? BioEssays, 22, 578-590.

Alié, A., Hiebert, L. S., Scelzo, M., \& Tiozzo, S. (2020). The eventful history

of nonembryonic development in tunicates. J Exp Zool Mol Dev Evol,

1-17. https://doi.org/10.1002/jez.b.22940

Baker, H. G. (1955). Self - compatibility and establishment after "longdistance"

dispersal. Evolution, 9, 347-349.

Banta, W. C. (1973). Evolution of avicularia in cheilostome Bryozoa. In

R. S. Boardman, A. H. Cheetham\&W. A.Oliver, Jr. (Eds.), Animal colonies:

Development and function through time (pp. 295-303). Dowden,

Hutchinson \& Ross.

Barbeitos, M. S., Romano, S. L., \& Lasker, H. R. (2010). Repeated loss of

coloniality and symbiosis in scleractinian corals. Proceedings of the

National Academy of Sciences of the United States of America, 107,

11877-11882.

Barlow, P. W. (1989). Meristems, metamers and modules and the

development of shoot and root systems. Botanical Journal of the

Linnean Society, 100, 255-279.

Barrington, E. (1967). Invertebrate structure and function. New York, NY:

Halstead Press.

Beklemishev, V. N. (1950). Towards the problem of individuality in

biology. Advances in Modern Biology, 29, 91-120.

Beklemishev, W. N. (1969). Principles of comparative anatomy of invertebrates [translated from the Russian]. Edinburgh, England: Oliver and Boyd.

Berning, B. (2008). Evidence for sublethal predation and regeneration 
among living and fossil ascophoran bryozoans. In S. J. Hageman, M. M. Key \& J.E. Winston (Eds.), Bryozoan Studies 2007 (15, pp. 1-7). Virginia Museum of Natural History Special Publication.

Blackstone, N. W., \& Jasker, B. D. (2003). Phylogenetic considerations of

clonality, coloniality, and mode of germline development in animals.

J Exp Zool B Mol Dev Evol, 297, 35-47.

Boardman, R. S., Cheetham, A. H., \& Oliver, W. A. J. (1973). Animal colonies.

Development and function through time. Stroudsburg, PA: Dowden,

Hutchinson \& Ross. Inc.

Bosch, T. C. G. (2009). Hydra and the evolution of stem cells. BioEssays, 31, 478-486.

Bouillon, J., Gravili, C., Pagès, F., Gili, J. M., \& Boero, F. (2006). An

introduction to Hydrozoa. Memoires du Museum National d'Histoire

Naturelle, 194, 1-591.

Brown, F. D., \& Swalla, B. J. (2012). Evolution and development of budding

by stem cells: Ascidian coloniality as a case study. Developmental

Biology, 369, 151-162.

Brown, F. D., Tiozzo, S., Roux, M. M., Ishizuka, K., Swalla, B. J., \& de

Tomaso, A. W. (2009). Early lineage specification of long - lived

germline precursors in the colonial ascidian Botryllus schlosseri.

Development, 136, 3485-3494.

Brusini, J., Robin, C., \& Franc, A. (2013). To fuse or not to fuse. An

evolutionary view of self - recognition systems. Journal of Phylogenetics

and Evolutionary Biology, 1, 2.

1749-1804>Buffon, G. L. (1749-1804). Histoire naturelle générale et

particulière. London, UK: W. Strahan and T. Cadell.

Burgess, S. C., Ryan, W. H., Blackstone, N. W., Edmunds, P. J.,

Hoogenboom, M. O., Levitan, D. R., \& Wulff, J. L. (2017). Metabolic

scaling in modular animals. Invertebrate Biology, 136, 456-472.

Buss, L. W. (1982). Somatic cell parasitism and the evolution of somatic tissue compatibility. Proceedings of the National Academy of Sciences of the United States of America, 79, 5337-5341.

Buss, L. W. (1983a). Somatic variation and evolution. Paleobiology, 9, 12-16.

Buss, L. W. (1983b). Evolution, development, and the units of selection. Proceedings of the National Academy of Sciences of the United States of America, 80, 1387-1391.

Buss, L. W. (1987). The Evolution of Individuality. Princeton, NJ: Princeton University Press.

Buss, L.W. (1979). Habitat selection, directional growth and spatial refuges:

Why colonial animals have more hiding places. In G. Larwood, B. R.

Rosen (Eds.), Biology and systematics of colonial organisms (pp. 459-497).

London, UK: Academic Press.

Buzgariu, W., Crescenzi, M., \& Galliot, B. (2014). Robust G2 pausing of

adult stem cells in Hydra. Differentiation, 87, 83-99.

Cadavid, L. F. (2005). Self/non - self discrimination in basal metazoa:

Genetics of allorecognition in the hydroid Hydractinia. Integrative and

Comparative Biology, 45, 623-630.

Carnevali, M. D. C. (2006). Regeneration in echinoderms: Repair, regrowth, cloning. Invertebrate Survival Journal, 3, 64-76.

Carpenter, M. A., Powell, J. H., Ishizuka, K. J., Palmeri, K. J., Rendulic, S., \& de Tomaso, A. W. (2011). Growth and long - term somatic and germline chimerism following fusion of juvenile Botryllus schlosseri. Biological Bulletin, 220, 57-70.

Carpenter, W. B. (1848). Zoology: a systematic account of the general structure, habits, instincts, and uses of the principal families of the animal kingdom. London, UK: Wm. S. Orr.

Carter, M. C., Gordon, D. P., \& Gardner, J. P. A. (2010a). Polymorphism and variation in modular animals: Morphometric and density analyses of bryozoan avicularia. Marine Ecology Progress Series, 399, 117-130. Carter, M. C., Gordon, D. P., \& Gardner, J. P. A. (2010b). Polymorphism and vestigiality: Comparative anatomy and morphology of bryozoan avicularia. Zoomorphology, 129, 195-211.

Cartwright, P. (2003). Developmental insights into the origin of complex colonial hydrozoans. Integrative and Comparative Biology, 43, 82-86.

Cartwright, P., \& Nawrocki, A. M. (2010). Character evolution in Hydrozoa (phylum Cnidaria). Integrative and Comparative Biology, 50, 456-472.

Chang, E. S., Orive, M. E., \& Cartwright, P. (2018). Nonclonal coloniality: Genetically chimeric colonies through fusion of sexually produced polyps in the hydrozoan Ectopleura larynx. Evolution Letters, 2, 442-455.

Cheetham, A. H. (1973). Study of cheilostome polymorphism using principal components analysis, Living and Fossil Bryozoa (pp.

385-409). London, UK: Academic Press.

Coelho, M. A. G., \& Lasker, H. R. (2014). Reproductive biology of the 
Caribbean brooding octocoral Antillogorgia hystrix. Invertebrate Biology, 133, 299-313.

Coma, R., Ribes, M., Gili, J., \& Zabala, M. (2000). Seasonality in coastal benthic ecosystems. Trends in Ecology and Evolution (Personal Edition), $15,448-453$.

Costa, J. T. (2006). The Other Insect Societies. Cambridge, MA: Harvard University Press.

Crowell, S. (1953). The regression - replacement cycle of hydranths of Obelia and Campanularia. Physiological Zoology, 26, 319-327.

Cáceres, C. E. (1997). Dormancy in Invertebrates. Invertebrate Biology, 116, 371-383.

Darwin, E. (1800). Phytologia: Or, the philosophy of agriculture and gardening.

With the theory of draining morasses and with an improved construction of the drill plough. Dublin, Ireland: P. Byrne.

Dayton, P. K., Robilliard, G. A., Paine, R. T., \& Dayton, L. B. (1974).

Biological accommodation in the Benthic Community at McMurdo

Sound, Antarctica. Ecological Monographs, 44, 105-128.

Deibel, D., \& Lowen, B. (2012). A review of the life cycles and life - history adaptations of pelagic tunicates to environmental conditions. ICES Journal of Marine Science, 69, 358-369.

de Tomaso, A. W. (2006). Allorecognition polymorphism versus parasitic stem cells. Trends in Genetics, 22, 485-490.

de Tomaso, A. W., Nyholm, S. V., Palmeri, K. J., Ishizuka, K. J., Ludington, W. B., Mitchel, K., \& Weissman, I. L. (2005). Isolation and

10 HIEBERT ET AL.

characterization of a protochordate histocompatibility locus. Nature, 438, 454-459.

Di Maio, A., Setar, L., Tiozzo, S., \& de Tomaso, A. W. (2015). Wnt affects symmetry and morphogenesis during post - embryonic development in colonial chordates. EvoDevo, 6, 17.

Dunn, C. W. (2009). Siphonophores. Current Biology, 19, R233-R234.

Dunn, C. W. (2005). Complex colony - level organization of the deep - sea siphonophore Bargmannia elongata (Cnidaria, Hydrozoa) is directionally asymmetric and arises by the subdivision of pro - buds. Developmental Dynamics, 234, 835-845.

Dunn, C. W., \& Wagner, G. P. (2006). The evolution of colony - level development in the Siphonophora (Cnidaria:Hydrozoa). Development Genes and Evolution, 216, 743-754.

Ellis, J. (1767). XLI. An account of the Actinia sociata, or clustered animalflower, lately found on the sea - coasts of the new - ceded islands: In a letter from John Elllis, Esquire, FRS to the Right Honourable the Earl of Hillsborough, FRS. Philosophical Transactions of the Royal Society of London, 428-437.

Extavour, C. G., \& Akam, M. (2003). Mechanisms of germ cell specification across the metazoans: Epigenesis and preformation. Development, 130, 5869-5884.

Frank, U., Plickert, G., \& Müller, W. A. (2009). Cnidarian interstitial cells: The dawn of stem cell research. In B. Rinkevich \& V. Matranga (Eds.), Stem cells in marine organisms (pp. 33-59). Dordrecht, Netherlands: Springer Netherlands.

Freeman, G. (1964). The role of blood cells in the process of asexual reproduction in the tunicate Perophora viridis. Journal of Experimental Zoology, 156, 157-183.

Funayama, N. (2013). The stem cell system in demosponges: Suggested involvement of two types of cells: Archeocytes (active stem cells) and choanocytes (food - entrapping flagellated cells). Development Genes and Evolution, 223, 23-38.

Gardner, S. N., \& Mangel, M. (1997). When can a clonal organism escape senescence? American Naturalist, 150, 462-490.

Gibson, S. (2012). On being an animal, or, the eighteenth - century zoophyte controversy in Britain. History of Science, 50, 453-476.

Gill, D. E., Chao, L., Perkins, S. L., \& Wolf, J. B. (1995). Genetic mosaicism in plants and clonal animals. Annual Review of Ecology and Systematics, 26 , 423-444.

Goldberg, E. E., Kohn, J. R., Lande, R., Robertson, K. A., Smith, S. A., \& Igić, B. (2010). Species selection maintains self - incompatibility. Science, 330, 493-495.

Goldsmith, O. (1774). A history of the earth and animated nature. London, UK: Caxton Press.

Gordon, D. P. (1977). The aging process in bryozoans. In R. Woollacott (Ed.), The biology of bryozoans (pp. 335-376). New York, NY: Academic Press.

Gould, S. J. (1977). Ontogeny and phylogeny. Cambridge, MA: Harvard 
University Press.

Grice, L. F., Gauthier, M. E. A., Roper, K. E., Fernàndez - Busquets, X., Degnan, S. M., \& Degnan, B. M. (2017). Origin and evolution of the sponge aggregation factor gene family. Molecular Biology and Evolution, 34, 1083-1099.

Grosberg, R. K. (1988). The evolution of allorecognition specificity in clonal invertebrates. Quarterly Review of Biology, 63, 377-412.

Grosberg, R. K., Hedgecock, D., \& Nelson, K. (2012). Invertebrate historecognition. New York, NY: Plenum Press.

Grosberg, R. K., Levitan, D. R., \& Cameron, B. B. (1996). Evolutionary genetics of allorecognition in the colonial hydroid Hydractinia symbiolongicarpus. Evolution, 50, 2221-2240.

Grosberg, R. K., \& Strathmann, R. R. (1998). One cell, two cell, red cell, blue cell: The persistence of a unicellular stage in multicellular life histories. Trends in Ecology and Evolution (Personal Edition), 13, 112-116.

Haeckel, E. (1866). Generelle Morphologie der Organismen. Allgemeine

Grundzüge der organischen Formen - Wissenschaft, mechanisch begründet durch die von C. Darwin reformirte Descendenz - Theorie, etc. Berlin,

Germany: G. Reimer.

Haeckel, E. (1904). The wonders of life: a popular study of biological philosophy. New York, NY: Harper \& Brothers.

Hageman, S. J. (2001). Growth patterns and complexity in colonial (modular) organisms. American Zoologist, 41(6), 1462. https://doi.org/10.1111/j.

1096 - 3642.2005.00179.x

Hand, C., \& Uhlinger, K. R. (1995). Asexual reproduction by transverse

fissionand some anomalies in the sea - anemone nematostellavectensis. Invertebrate Biology, 114, 9-18.

Harmer, S. F. (1886). On the life - history of Pedicellina. Quarterly Journal of Microscopical Science, 27, 239-263.

Harper, J. L. (1977). Population biology of plants. London, UK: Academic Press.

Harper, J. L. (1980). Plant demography and ecological theory. Oikos, 35, 244-253.

Harper, J. L. (1985). Modules, branches, and the capture of resources. In J. B. C. Jackson, L. W. Buss \& R. E. Cook (Eds.), Population biology and evolution of clonal organisms (pp. 1-33). New Haven, CT: Yale University Press.

Harvell, C. D. (1990). The ecology and evolution of inducible defenses. Quarterly Review of Biology, 65, 323-340.

Harvell, C. D. (1991). Coloniality and inducible polymorphism. American Naturalist, 138, 1-14.

Harvell, C. D. (1994). The evolution of polymorphism in colonial invertebrates and social insects. Quarterly Review of Biology, 69, 155-185.

Hayward, P. J. (1995). Antarctic cheilostomatous bryozoa, Oxford, UK: Oxford University.

He, J., Zheng, L., Zhang, W., \& Lin, Y. (2015). Life cycle reversal in Aurelia sp.1 (Cnidaria, Scyphozoa). PLOS One, 10, e0145314.

Henry, L. - A., \& Hart, M. (2005). Regeneration from Injury and resource allocation in sponges and corals-a Review. Int Rev Hydrobiol, 90, 125-158.

Hiebert, L. S., Vieira, E. A., Dias, G. M., Tiozzo, S., \& Brown, F. D. (2019).

Colonial ascidians strongly preyed upon, yet dominate the substrate in a subtropical fouling community. Proceedings of the Royal Society B: Biological Sciences, 286, 20190396.

Hughes, D. J., \& Jackson, J. B. C. (1990). Do constant environments promote complexity of form? The distribution of bryozoan polymorphism as a test of hypotheses. Evolution, 44, 889-905.

Hughes, R. N. (1989). Functional biology of clonal animals. New York, NY: Springer Science \& Business Media.

Hughes, R. N. (2005). Lessons in modularity: The evolutionary ecology of colonial invertebrates. Sci Mar, 69, 169-179.

Hughes, R. N., Manríquez, P. H., Morley, S., Craig, S. F., \& Bishop, J. D.

D. (2004). Kin or self - recognition? Colonial fusibility of the bryozoan Celleporella hyalina. Evolution \& Development, 6 , 431-437.

Huxley, J. (1912). The individual in the animal kingdom. Cambridge, UK: Cambridge University Press.

Huxley, T. H. (1852). Upon animal individuality. Proceedings of the Royal Institution, i, 184-189.

Jablonski, D., Lidgard, S., \& Taylor, P. D. (1997). Comparative ecology of bryozoan radiations: Origin of novelties in cyclostomes and cheilostomes. Palaios, 12, 505-523. 
Jackson, J. B. C. (1977). Competition on marine hard substrata: The adaptive significance of solitary and colonial strategies. American Naturalist, 111, 743-767.

Jackson, J. B. C., Buss, L. W., Cook, R. E., \& Ashmun, J. W. (1985)

Population biology and evolution of clonal organisms, New Haven:

Yale University Press.

HIEBERT ET AL. | 11

Jackson, J. B. C., \& Coates, A. G. (1986). Life cycles and evolution of clonal (modular) animals. Philosophical Transactions of the Royal Society of

London. Series B, Biological Sciences, 313, 7-22.

Johnston, G. (1847). A History of the British Zoophytes. London, UK: J. Van

Voorst.

Kassmer, S. H., Langenbacher, A., \& de Tomaso, A. W. (2019). Integrinalpha $6_{+}$stem cells (ISCs) are responsible for whole body

regeneration in an invertebrate chordate. bioRxiv, https://doi.org/10.

$1101 / 647578$

Kawamura, K., \& Fujiwara, S. (1995). Cellular and molecular characterization

of transdifferentiation in the process of morphallaxis of budding

tunicates. Seminars in Cell Biology, 6, 117-126.

Kayal, E., Bentlage, B., Sabrina Pankey, M., Ohdera, A. H., Medina, M.,

Plachetzki, D. C., ... Ryan, J. F. (2018). Phylogenomics provides a robust topology of the major cnidarian lineages and insights on the origins of key organismal traits. BMC Evolutionary Biology,

$18,68$.

Kim, K., \& Lasker, H. R. (1998). Allometry of resource capture in colonial cnidarians and constraints on modular growth. Functional Ecology, 12,

646-654.

Kirkwood, T. B. L. (1977). Evolution of ageing. Nature, 270, 301-304.

Kirkwood, T. B. L., \& Austad, S. N. (2000). Why do we age? Nature, 408, 233-238.

Kluge, G. A. (1975). Bryozoa of the northern seas of the USSR. New Delhi:

Amerind Publishing Co.

Kott, P. (1981). Replication in the Ascidiacea: an adaptive strategy in the

coral reef environment. Proceedings of the fourth international coral reef symposium, 2, 725-733.

Koziol, C., Borojevic, R., Steffen, R., \& Müller, W. E. (1998). Sponges

(Porifera) model systems to study the shift from immortal to

senescent somatic cells: The telomerase activity in somatic cells.

Mechanisms of Ageing and Development, 100, 107-120.

Kürn, U., Rendulic, S., Tiozzo, S., \& Lauzon, R. J. (2011). Asexual propagation and regeneration in colonial ascidians. Biological Bulletin, 221, 43-61.

Laird, D. J., \& Weissman, I. L. (2004). Telomerase maintained in selfrenewing tissues during serial regeneration of the urochordate

Botryllus schlosseri. Developmental Biology, 273, 185-194.

Lang, W. D. (1921). Catalogue of the fossil of bryozoa (polyzoa) in the

Department of Geology, British Museum (Natural History). London, UK:

British Museum.

Lauzon, R. J., Rinkevich, B., Patton, C. W., \& Weissman, I. L. (2000). A

morphological study of nonrandom senescence in a colonial urochordate.

Biological Bulletin, 198, 367-378.

Leuckart, R. (1851). Über den Polymorphismus der Individuen oder die

Erscheinungen der Arbeitstheilung in der Natur: ein Beitrag zur Lehre vom Generationswechsel. De Gruyter, Incorporated.

Lidgard, S., Carter, M. C., Dick, M. H., Gordon, D. P., \& Ostrovsky, A. N.

(2012). Division of labor and recurrent evolution of polymorphisms in

a group of colonial animals. Evolution \& Ecology, 26, 233-257.

López - Otín, C., Blasco, M. A., Partridge, L., Serrano, M., \& Kroemer, G. (2013). The hallmarks of aging. Cell, 153, 1194-1217.

Mackie, G. O., Harper, J. L., Rosen, B. R., \& White, J. (1986). From

aggregates to integrates: Physiological aspects of modularity in colonial animals. Philosophical Transactions of the Royal Society of

London. Series B, Biological Sciences, 313, 175-196.

Maklakov, A. A., \& Immler, S. (2016). The expensive germline and the

evolution of ageing. Current Biology, 26, R577-R586.

Marfenin, N. N. (1997). Adaptation capabilities of marine modular

organisms. In A.D Naumov, H. Hummel, A. A. Sukhotin \& J. S.

Ryland (Eds.), Interactions and Adaptation Strategies of Marine

Organisms. Developments in Hydrobiology (121, p. 153158).

Dordrecht: Springer.

Maynard - Smith, J. (1978). The evolution of sex. Cambridge, UK: Cambridge University Press.

McKinney, F. K., \& Jackson, J. B. C. (1989). Bryozoan Evolution. Chicago, IL:

University of Chicago Press. 
McKitrick, T. R., \& de Tomaso, A. W. (2010). Molecular mechanisms of allorecognition in a basal chordate. Seminars in Immunology, 22, 34-38. McShea, D. W. (2001). The minor transitions in hierarchical evolution and the question of a directional bias. Journal of Evolutionary Biology, 14, 502-518.

McShea, D. W. (2002). A complexity drain on cells in the evolution of multicellularity. Evolution, 56, 441-452.

McShea, D. W., \& Changizi, M. A. (2003). Three puzzles in hierarchical evolution. Integrative and Comparative Biology, 43, 74-81.

Medawar, P. B. (1952). Uniqueness of the Individual. In P. B. Medawar (Ed.), An Unsolved Problem of Biology. London, UK: H.K. Lewis.

Munro, C., Siebert, S., Zapata, F., Howison, M., Damian - Serrano, A., Church, S. H., ... Dunn, C. W. (2018). Improved phylogenetic resolution within Siphonophora (Cnidaria) with implications for trait evolution.

Molecular Phylogenetics and Evolution, 127, 823-833.

Nawrocki, A. M., \& Cartwright, P. (2012). A novel mode of colony formation in a hydrozoan through fusion of sexually generated individuals. Current Biology, 22, 825-829.

Nawrocki, A. M., \& Cartwright, P. (2013). Expression of Wnt pathway

genes in polyps and medusa - like structures of Ectopleura larynx

(Cnidaria: Hydrozoa). Evolution \& Development, 15, 373-384.

Nekliudova, U. A., Shunkina, K. V., Grishankov, A. V., Varfolomeeva, M. A., Granovitch, A. I., \& Ostrovsky, A. N. (2019). Colonies as dynamic systems: Reconstructing the life history of Cribrilina annulata

(Bryozoa) on two algal substrates. Journal of the Marine Biological Association of the United Kingdom, 99, 1363-1377.

Nicotra, M. L. (2019). Invertebrate allorecognition. Current Biology, 29, R463-R467.

Sköld, H. N., \& Obst, M. (2011). Potential for clonal animals in longevity and ageing studies. Biogerontology, 12, 387-396.

Nyhart, L. K., \& Lidgard, S. (2011). Individuals at the center of biology:

Rudolf Leuckart's Polymorphismus der Individuen and the ongoing narrative of parts and wholes. With an annotated translation. Journal of the History of Biology, 44, 373-443.

O'Dea, A. (2006). Asexual propagation in the marine bryozoan Cupuladria exfragminis. Journal of Experimental Marine Biology and Ecology, 335, 312-322.

O'Dea, A., \& Jackson, J. (2009). Environmental change drove macroevolution in cupuladriid bryozoans. Proceedings of the Royal Society B: Biological Sciences, 276, 3629-3634.

O'Dea, A., Jackson, J. B. C., Taylor, P. D., \& Rodriguez, F. (2008). Modes of reproduction in Recent and fossil cupuladriid bryozoans. Palaeontology, 41, 847-864.

O'Dea, A., Ostrovsky, A. N., \& Rodriguez, F. (2010). Embryonic brooding and clonal propagation in tropical eastern Pacific cupuladriid

bryozoans. Journal of the Marine Biological Association of the United Kingdom, 90, 291-299.

Orive, M. E. (1995). Senescence in organisms with clonal reproduction and complex life histories. American Naturalist, 145, 90-108.

Ostrovsky, A. N. (2013). Evolution of sexual reproduction in marine invertebrates: Example of gymnolaemate bryozoans. Dordrecht, Netherlands: Springer. Ostrovsky, A. N., \& Taylor, P. D. (2005). Brood chambers constructed from spines in fossil and Recent cheilostome bryozoans. Zoological Journal of the Linnean Society, 144(3), 317-361.

Owen, R. (1856). Lectures on the comparative anatomy and physiology of the invertebrate animals. British and Foreign Medico - Chirurgical Review, 18, 1-27.

Palumbi, S. R., \& Jackson, J. B. C. (1983). Aging in modular organisms: Ecology of zooid senescence in Steginoporella sp. (Bryozoa; Cheilostomata). Biological Bulletin, 164, 267-278.

Pannell, J. R., Auld, J. R., Brandvain, Y., Burd, M., Busch, J. W., Cheptou, P. - O., ... Winn, A. A. (2015). The scope of Baker's law. New Phytologist, $208,656-667$.

12 | HIEBERT ET AL.

Perrier, E. (1881). Les colonies animales et la formation des organismes. Paris, France: Masson.

Philipp, I., Aufschnaiter, R., Ozbek, S., Pontasch, S., Jenewein, M.,Watanabe, H., ...Hobmayer, B. (2009). Wnt/beta - catenin and noncanonicalWnt signaling interact in tissue evagination in the simple eumetazoan Hydra. Proceedings of the National Academy of Sciences of the United States of America, 106, 4290-4295.

Piraino, S., Boero, F., Aeschbach, B., \& Schmid, V. (1996). Reversing the life cycle: Medusae transforming into polyps and cell transdifferentiation in Turritopsis nutricula (Cnidaria, Hydrozoa). Biological Bulletin, 190, 
302-312.

Piraino, S., de Vito, D., Schmich, J., Bouillon, J., \& Boero, F. (2004). Reverse

development in Cnidaria. Canadian Journal of Zoology, 82, 1748-1754.

Prünster, M. M., Ricci, L., Brown, F. D., \& Tiozzo, S. (2019a). Modular cooption

of cardiopharyngeal genes during non - embryonic myogenesis.

EvoDevo, 10, 3

Prünster, M. M., Ricci, L., Brown, F. D., \& Tiozzo, S. (2019b). De novo

neurogenesis in a budding chordate: Co - option of larval anteroposterior

patterning genes in a transitory neurogenic organ. Developmental Biology,

448, 342-352.

Pugh, P. R. (2003). A revision of the family Forskaliidae (Siphonophora,

Physonectae). Journal of Natural History, 37, 1281-1327.

Ramirez, L. E. (2002). Fecundity and life - history strategies in marine

invertebrates. Advances in Marine Biology, 43, 87-170.

Reichard, M. (2017). Evolutionary perspectives on ageing. Seminars in Cell

and Developmental Biology, 70, 99-107.

Reinhardt, B., Broun, M., Blitz, I. L., \& Bode, H. R. (2004). HyBMP5 - 8b, a

BMP5 - 8 orthologue, acts during axial patterning and tentacle

formation in hydra. Developmental Biology, 267, 43-59.

Ricci, L., Chaurasia, A., Lapébie, P., Dru, P., Helm, R. R., Copley, R. R., \&

Tiozzo, S. (2016). Identification of differentially expressed genes from

multipotent epithelia at the onset of an asexual development.

Scientific Reports, 6, 27357.

Roark, E. B., Guilderson, T. P., Dunbar, R. B., Fallon, S. J., \& Mucciarone, D. A.

(2009). Extreme longevity in proteinaceous deep - sea corals. Proceedings

of the National Academy of Sciences of the United States of America, 106,

5204-5208.

Rosen, B. R. (1979). Modules, members and communes: A postscript introduction to social organisms. Biology and systematics of colonial organisms. In G. Larwood \& B. R. Rosen (Eds.), pp. xiii-xxxv. London,

UK: Academic Press.

Rosengarten, R. D., \& Nicotra, M. L. (2011). Model systems of invertebrate allorecognition. Current Biology, 21, R82-R92.

Rosental, B., Kowarsky, M., Seita, J., Corey, D. M., Ishizuka, K. J.,

Palmeri, K. J., ... Voskoboynik, A. (2018). Complex mammalian - like

haematopoietic system found in a colonial chordate. Nature, 564,

425-429.

Ryland, J. S. (1976). Physiology and ecology of marine bryozoans. In F. S

Russell \& M. Yonge (Eds.), Advances in Marine Biology (Vol. 14, pp.

285-443). London, UK: Academic Press.

Saló, E. (2006). The power of regeneration and the stem - cell kingdom:

Freshwater planarians (Platyhelminthes). BioEssays, 28, 546-559.

Sanders, S. M., Shcheglovitova, M., \& Cartwright, P. (2014). Differential

gene expression between functionally specialized polyps of the

colonial hydrozoan Hydractinia symbiolongicarpus (Phylum Cnidaria).

BMC Genomics, 15, 406.

Schack, C. R., Gordon, D. P., \& Ryan, K. G. (2019). Modularity is the mother of invention: A review of polymorphism in bryozoans. Biological

Reviews, 94, 773-809.

Schenkelaars, Q., Tomczyk, S., Wenger, Y., Ekundayo, K., Girard, V.,

Buzgariu, W., ... Galliot, B. (2017). Hydra, a model system for deciphering the mechanisms of aging and resistance to aging. bioRxiv, https://doi.org/10.1101/155804

Schmid, V., Wydler, M., \& Alder, H. (1982). Transdifferentiation and regeneration in vitro. Developmental Biology, 92, 476-488.

Schwaha, T. F., Ostrovsky, A. N., \& Wanninger, A. (2020). Key novelties in

the evolution of the aquatic colonial phylum Bryozoa: Evidence from

soft body morphology. Biological Reviews: Cambridge Philosophical

Society, https://doi.org/10.1111/brv.12583

Shukalyuk, A., Isaeva, V., Kizilova, E., \& Baiborodin, S. (2005). Stem cells in

the reproductive strategy of colonial rhizocephalan crustaceans

(Crustacea: Cirripedia: Rhizocephala). Invertebrate Reproduction \&

Development, 48, 41-53.

Siebert, S., Goetz, F. E., Church, S. H., Bhattacharyya, P., Zapata, F.,

Haddock, S. H. D., \& Dunn, C. W. (2015). Stem cells in Nanomia bijuga

(Siphonophora), a colonial animal with localized growth zones.

EvoDevo, 6, 22.

Siebert, S., Robinson, M. D., Tintori, S. C., Goetz, F., Helm, R. R., Smith, S. A., ..

Dunn, C. W. (2011). Differential gene expression in the siphonophore

Nanomia bijuga (Cnidaria) assessed with multiple next - generation

sequencing workflows. PLOS One, 6, e22953.

da Silveira, F. L., Jarms, G., \& Morandini, A. C. (2002). Experiments in

nature and laboratory observations with Nausithoe Aurea 
(Scyphozoa: Coronatae) support the concept of perennation by tissue saving and confirm dormancy. Biota Neotropica, 2, 1-25.

Silén, L. (1977). Polymorphism. In R. M. Woollacott \& R. L. Zimmer (Eds.), Biology of bryozoans (pp. 183-231). New York, NY: Academic Press.

Simpson, C. (2012). The evolutionary history of division of labour.

Proceedings of the Royal Society B: Biological Sciences, 279, 116-121.

Simpson, C. (2011). How many levels are there? How insights from evolutionary transitions in individuality help measure the hierarchical complexity of life. In B. Calcott (Ed.), The major transitions in evolution revisited (pp. 199-226). Cambridge, MA: MIT Press.

Simpson, C., Jackson, J. B. C., \& Herrera - Cubilla, A. (2017). Evolutionary determinants of morphological polymorphism in colonial animals.

American Naturalist, 190, 17-28.

Simpson, C., Herrera - Cubilla, A., \& Jackson, J. (2020). How colonial animals evolve. Science Advances, 6(2), https://doi.org/10.1126/sciadv. aaw9530

Sköld, H. N., Asplund, M. E., Wood, C. A., \& Bishop, J. D. D. (2011).

Telomerase deficiency in a colonial ascidian after prolonged asexual propagation. Journal of Experimental Zoology B: Molecular Development \& Evolution, 316, 276-283.

Sköld, H. N., Obst, M., Sköld, M., \& Åkesson, B. (2009). Stem cells in asexual reproduction of marine invertebrates. In B. M. V. Rinkevich (Ed.), Stem cells in marine organisms (pp. 105-137). Dordrecht, Netherlands: Springer.

Spencer, H. (1904). First Principles. London, UK: Williams \& Norgate. Stebbing, A. R. D. (1970). Aspects of the reproduction and life cycle of Rhabdopleura compacta (Hemichordata). Marine Biology, 5, 205-212. Stebbins, G. L. (1957). Self fertilization and population variability in the higher plants. American Naturalist, 91, 337-354.

Stoner, D. S., Rinkevich, B., \& Weissman, I. L. (1999). Heritable germ and somatic cell lineage competitions in chimeric colonial protochordates. Proceedings of the National Academy of Sciences of the United States of America, 96, 9148-9153.

Szathmáry, E., \& Smith, J. M. (1995). The major evolutionary transitions. Nature, 374, 227-232.

Tan, T. C. J., Rahman, R., Jaber - Hijazi, F., Felix, D. A., Chen, C., Louis, E. J., \& Aboobaker, A. (2012). Telomere maintenance and telomerase activity are differentially regulated in asexual and sexual worms. Proceedings of the National Academy of Sciences of the United States of America, 109, 4209-4214.

Tiozzo, S., Christiaen, L., Deyts, C., Manni, L., Joly, J. - S., \& Burighel, P. (2005). Embryonic versus blastogenetic development in the compound ascidian Botryllus schlosseri: Insights from Pitx expression patterns. Developmental Dynamics, 232, 468-478.

Tiozzo, S., \& Copley, R. R. (2015). Reconsidering regeneration in

metazoans: An evo - devo approach. Frontiers in Ecology and

Evolution, 3, 67.

HIEBERT ET AL. $\mid 13$

Tiozzo, S., \& de Tomaso, A. W. (2009). Functional analysis of Pitx during asexual regeneration in a basal chordate. Evolution \& Development, 11, 152-162.

Treibergs, K. A. (2019). How does a polymorphic colony divide labor among its modules? Colonial development in the marine invertebrate, Bugulina stolonifera (Doctoral dissertation). Harvard University, Graduate School of Arts \& Sciences, Cambridge, MA.

Trembley, A. (1986). Memoirs concerning the natural history of the type of freshwater polyp with arms shaped like horns. Pacific Grove, CA:

Boxwood Press.

van Valen, L. (1978). Arborescent animals and other colonoids. Nature, $276,318$.

Veron, J., Stafford - Smith, M., DeVantier, L., \& Turak, E. (2015). Overview of distribution patterns of zooxanthellate Scleractinia. Frontiers in Marine Science, 1, 435.

Vieira, L. M., Spencer Jones, M. E., Winston, J. E., Migotto, A. E., \& Marques, A. C. (2014). Evidence for polyphyly of the genus

Scrupocellaria (Bryozoa: Candidae) based on a phylogenetic analysis of morphological characters. PLOS One, 9, e95296.

Vogt, C. (1847). Lehrbuch der Geologie und Petrefactenkunde, 2 vols. Braunschweig, Germany: F. Vieweg.

Voskoboynik, A., \& Weissman, I. L. (2015). Botryllus schlosseri, an emerging model for the study of aging, stem cells, and mechanisms of regeneration. Invertebrate Reproduction \& Development, 59, 33-38. Wallace, R. L. (1987). Coloniality in the phylum Rotifera. Hydrobiologia, 
$147,141-155$

Warner, J. F., Amiel, A. R., Johnston, H., \& Röttinger, E. (2019). bioRxiv,

https://doi.org/10.1101/658930

Weismann, A. (1893). The germ - plasm: a theory of heredity. New York, NY:

Scribner's.

West, S. A., Lively, C. M., \& Read, A. F. (1999). A pluralist approach to sex

and recombination. Journal of Evolutionary Biology, 12, 1003-1012.

Wheeler, W. M. (1911). The ant - colony as an organism. Journal of

Morphology, 22, 307-325.

Whittle, C. A., \& Extavour, C. G. (2017). Causes and evolutionary consequences of primordial germ - cell specification mode in metazoans.

Proceedings of the National Academy of Sciences of the United States of

America, 114, 5784-5791.

Williams, G. G. (1986). Retrospect on modular organisms. Philosophical

Transactions of the Royal Society, B: Biological Sciences, 313, 245-250.

Wilson, D. S., \& Sober, E. (1989). Reviving the superorganism. Journal of

Theoretical Biology, 136, 337-356.

Wilson, E. (1975). Sociobiology: The new synthesis. Cambridge, MA

Harvard.

Winston, J. E. (2010). Life in the colonies: Learning the alien ways

of colonial organisms. Integrative and Comparative Biology, 50 ,

919-933.

Zimmer, R. (1991). Phoronida. In A. C. Giese, J. S. Pearse \& V. B. Pearse

(Eds.), Reproduction of marine invertebrates, Vol. Vl: Echinoderms and

lophophorates (pp. 1-45). Pacific Grove, CA: Boxwood Press.

How to cite this article: Hiebert LS, Simpson C, Tiozzo S.

Coloniality, clonality, and modularity in animals: The elephant

in the room. J Exp Zool (Mol Dev Evol). 2020;1-14.

https://doi.org/10.1002/jez.b.22944

14 | HIEBERT ET AL. 